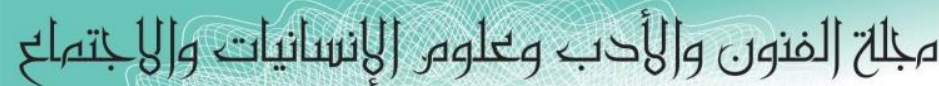

Journal of Arts, Literature, Humanities and Social Sciences

ISSN online: 2414 - 3383

ISSN print: 2616 - 3810

العدد (41) آب - أغسطس 2019

\title{
فاعلية أنموذج فلاندرز المعرفي في تحصيل مادة قواعد اللغة العربية عند طلاب الصفف الأول متوسط في فادة
}

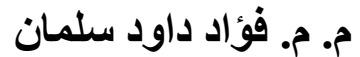 \\ المديرية العامة لتربية محافظة ديالى دانى

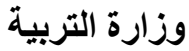 \\ العراق الترية \\ Email: funddaud46@gmail.com
}

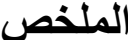

هدف البحث إلى تعرف ( فاعلية أنموذج فلاندرز المعرفي في تحصيل مـادة قواعد اللغـة العربيـة عند طلاب الصف الأول متوسط) ولتحقيق هدف البحث صـاغ الباحث الفرضية الصفرية (لا يوجد فرق ذو دلالة إحصـائية عند مستوى (0.05) بين متوسط درجات طلاب المجمو عة التجرييية الذين يدَّرسُون قو اعد اللغة العربية على وفق أنموذج فلاندرز المعرفي ، وبين متوسط درجات طلاب المجموعـة الضـابطة الذين يدُرَّسون قو اعد اللغنة

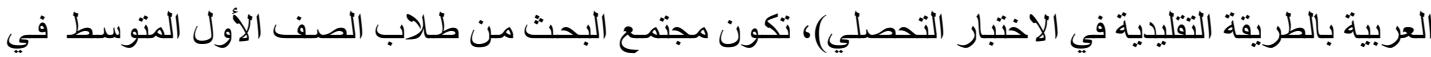

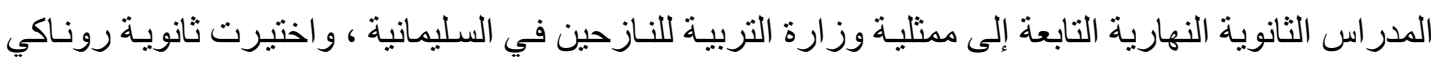
للبنين قصدياً لتكون عينة للبحث وبالطريقة العشو ائية البسيطة اختيرت شعبة (ب) لتمثل المجموعـة التجريبية و عدد طلابها (31) وشعبة (أ) المجموعـة الضـابطة وعدد طلابها (30) طالباً ، كافأ الباحث بين مجمو عتي البحث ( التجريبية و الضابطة) إحصـائياً في متغير (درجات القواعد لمجمو عتي في الفصل الدراسي الأول ،

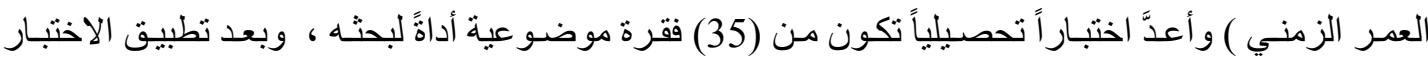
ومعالجة البيانات إحصائياً ظهر أن هناك فرق ذو دلالة إحصـئية لمصلحة المجموعة التجريبية ، وفي ضونئه أوصى الباحث بتوصيات ومنها الاهنمام بالنمإذج التعليمية الحديثة بعامة و أنموذج فلاندرز بخاصـة في عملية تدريس قو اعد اللغة العربية في الصف الأول منوسط. 


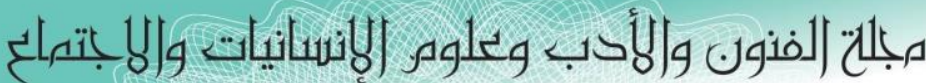

Journal of Arts, Literature, Humanities and Social Sciences

ISSN online: 2414 - 3383

ISSN print: 2616 - 3810

آب -أغسطس 2019

العدد (41)

\title{
The Effectiveness of the Flanders Cognitive Model in the Collection of Arabic Grammar for Grade first Student
}

\author{
Assist. Lect. Fouad Dawood Salman \\ Ministry of Education Iraq \\ Directorate General of Diyala \\ Iraq
}

\begin{abstract}
The aim of the research is to identify (The Effectiveness of the Flanders Cognitive Model in the Collection of Arabic Grammar for Grade first Students average) and to achieve the research goal the researcher formulated a zero hypothesis (there is no statistically significant difference at the level $(0,05)$ between the average scores of experimental group Student who student grammar According to the Flanders cognitive model, and among the average scores of the control group students who teach Arabic grammar in the traditional way in the Achievement Test, the research community consisted of the first intermediate students in the daytime secondary schools affiliated with the representative of the Ministry of Education for ID ps. Rona Ki Secondary School for Boys was chosen intentionally to be a sample of research. Variable( Grades of the rules for my group in the first semester, chronological age) and prepared an achievement test consisting of (45) substantive paragraphs as a tool for his research, and after the application of the test and date processing statistically it appeared that there is a statistically significant difference for the benefit of the experimental group, and in the light of the researcher recommended recommendations, including uh Mam modern educational models in general and in particular the model of Flanders in the process of teaching the first grade average.
\end{abstract}




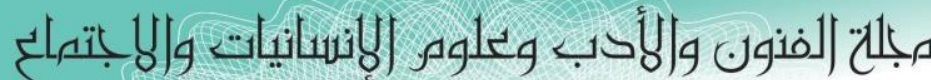

Journal of Arts, Literature, Humanities and Social Sciences

ISSN online: 2414 - 3383

ISSN print: 2616 - 3810

\section{العدد (41) آب - أغسطس 2019}

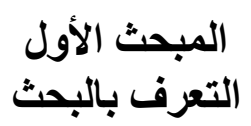

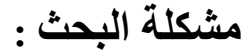

يعاني طلاب الصف الأول المتوسط من صعوبة في مادة اللغة العربية بعامة وفي قو اعد اللغة العربية بخاصة ، مما أدى الى ضعف في في تحصيلهم المعرفي فيها ونفور هم منها ، و هذا ما لحظه الباحثث عبر تدريسه للغة العة العربية

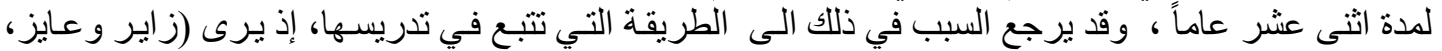

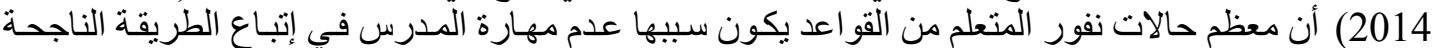

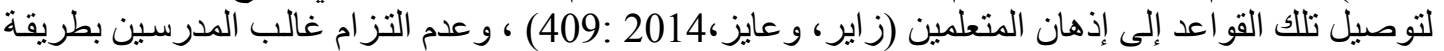

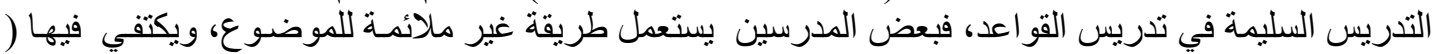

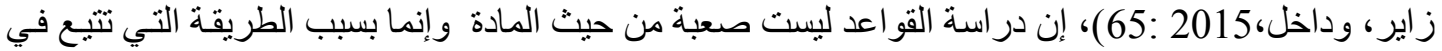

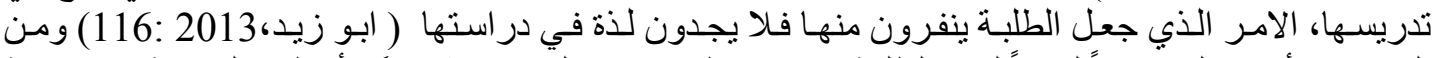

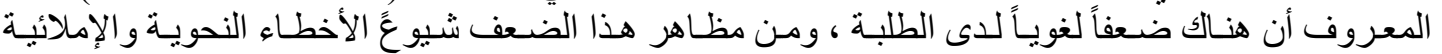

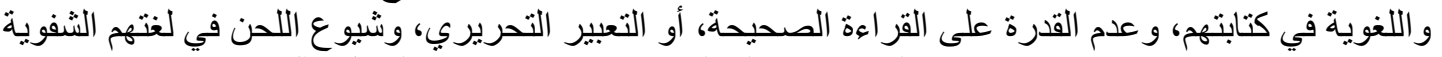

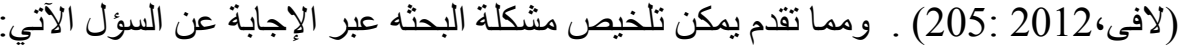
( هل لإنموذج فلاندرز اثر في تحصيل مادة قو اعد اللغة العربية عند طلاب الصف الصف الأول ).

أهمية البحث: الإند:

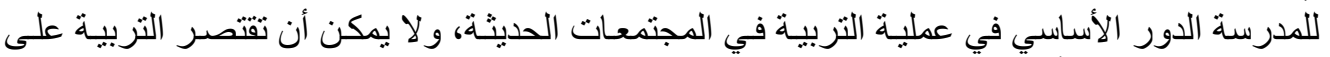

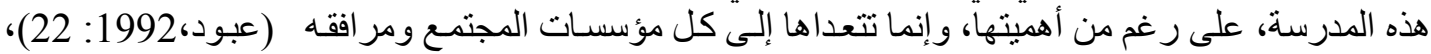

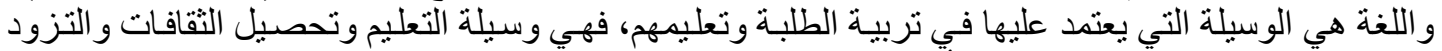

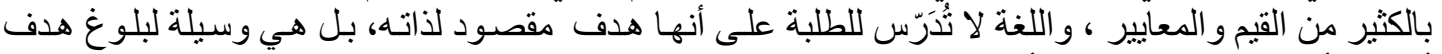

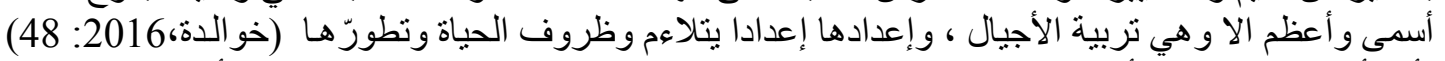

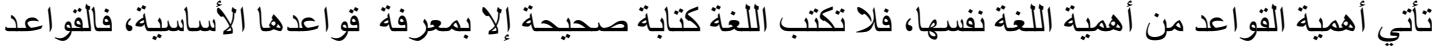

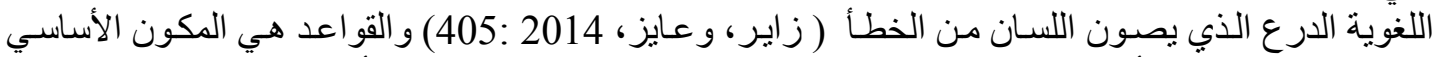

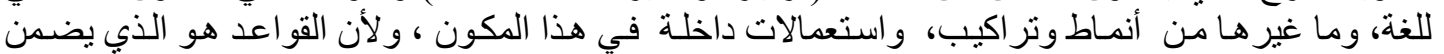

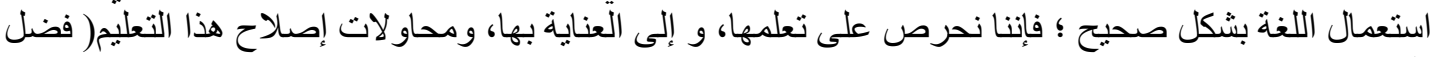

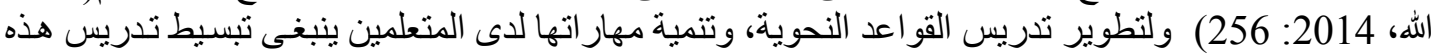

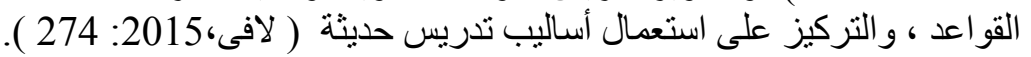

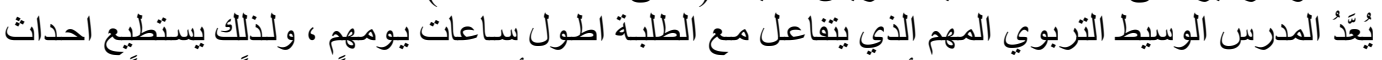

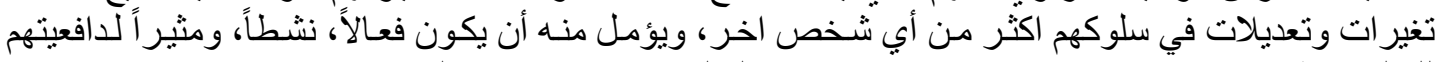

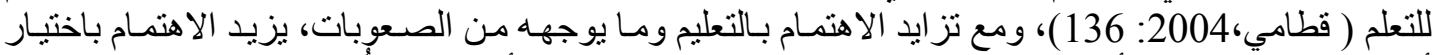

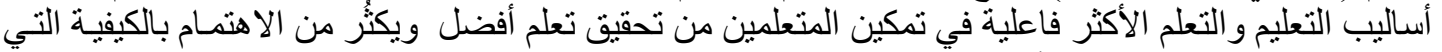

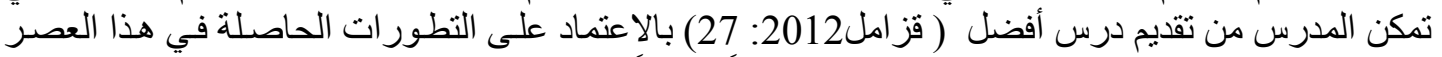

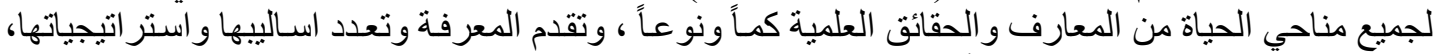

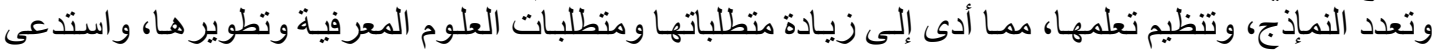

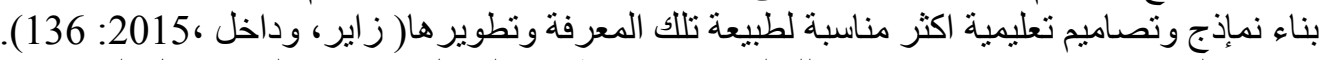

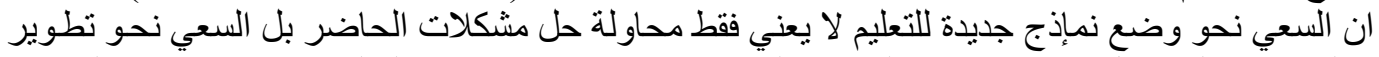

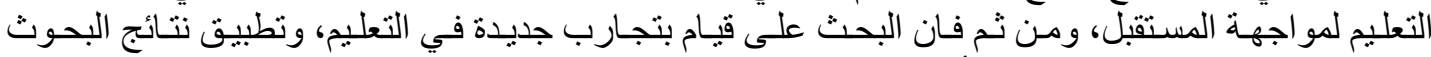

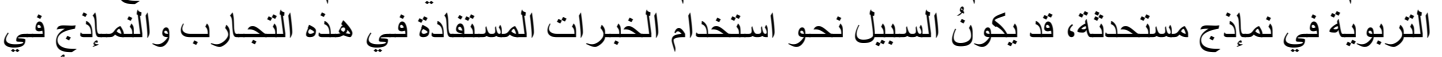

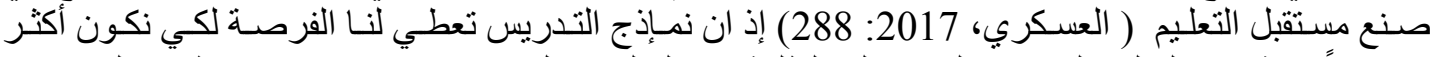

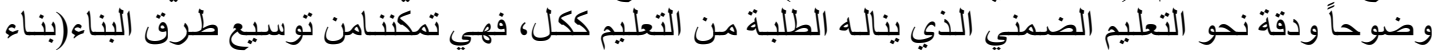

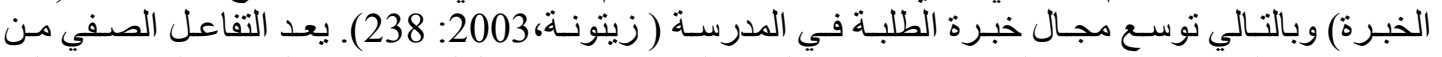
الاستحدثات التربوية الإيجابية التي اسهمت في تخليص المدرس من دور الملقن صاحب المعرفة الذي تقع على 


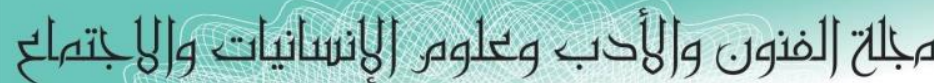

Journal of Arts, Literature, Humanities and Social Sciences

ISSN online: 2414 - 3383

ISSN print: 2616 - 3810

\section{العدد (41) آب - أغسطس 2019}

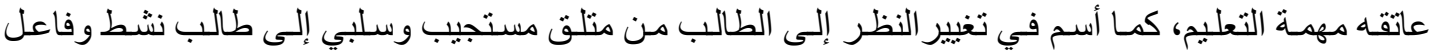

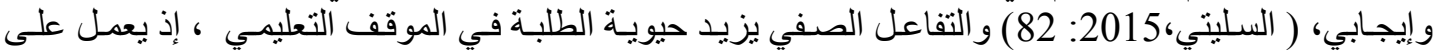

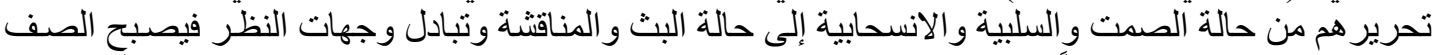

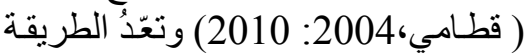

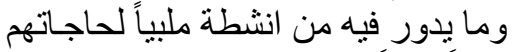

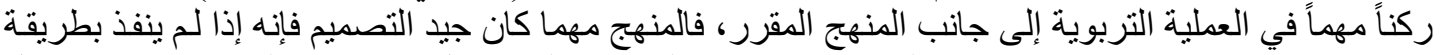

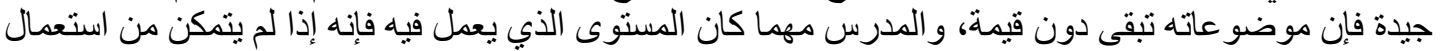

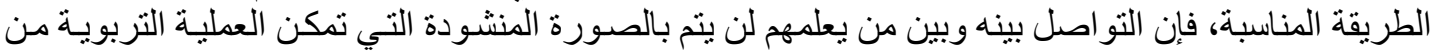

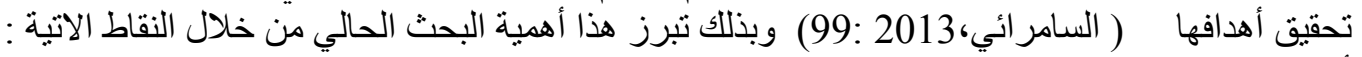

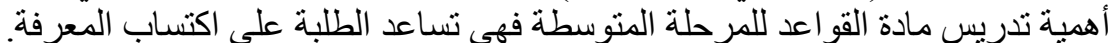

أهمية استعمال النمإذج و الاستراتيجيات الحديثة في تطوير تدريس اللغة العربية بشكل عام والقو اعد بشكل خاص. 3. يساعد أنموذج فلاندرز المعرفي في اثارة اهتمام الطلبة ودفعم للتعلم، وانتقال اثر التعلم بشكل أفضل.

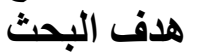

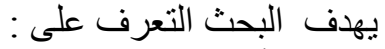
فاعلية أنموذج فلاندرز المعرفي في تحصيل مادة قو اعد اللغة العربية لدى طلاب الصف الأول متوسط.

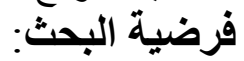
ولتحقيق هدف البحث صاغ الباحث الفرضية الصفرية الآتية :

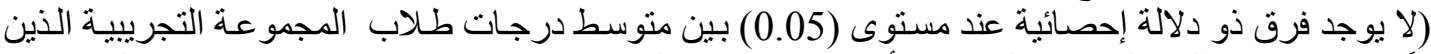

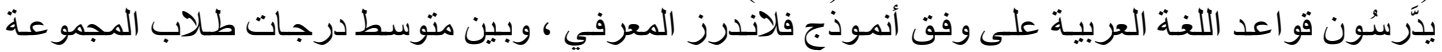
الضابطة الذين يُرُّسون قو اعد اللغة العربية بالطريقة التقليدية في الاختبار التحصل). حدود البحث النئ 1. المـارس المتوسطة و الثانويـة النهاريـة للبنين التابعـة التنابعة لمثنليـة وزارة التربيـة للنـازحين في السليمانية ( $2019-2018$ ) 2. عينة من طلبة الصف الأول المتوسط في ثانويـة رونـاكي للبنين التابعة لممثلية وز ارة التربيـة للنازحين في

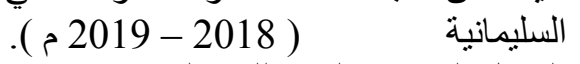
3. الفصل الدراسي الثاني للعام الدراسي 2018م-2019 2019.

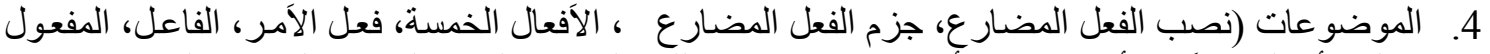

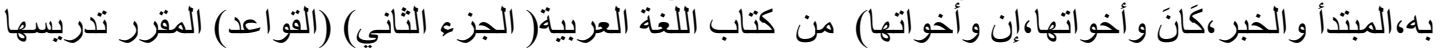
لطلبة الصف الأول منوسط للعام الدراسي 2018 م-2019م . تحليد المصطلحات : المبل

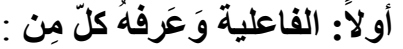

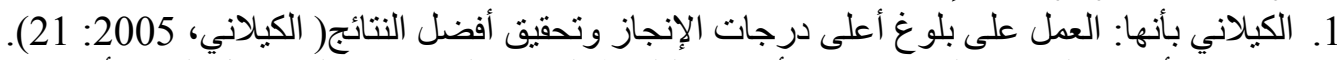

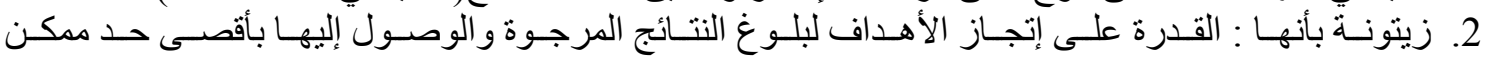

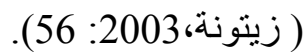
•• التعريف الاجر ائي للفاعلية بأنهُ: قدرة أنموذج فلاندرز في التأثيير على تحصيل مادة القو اعد لطلاب الصف الأول متوسط ( الدجمو عة التجريبية).

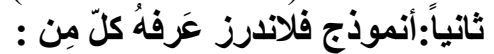

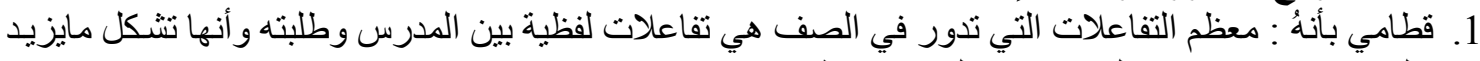

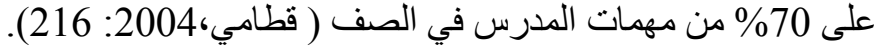
التعريف الاجر ائي:بأنهُ النتيجة التي تبين مدى تأثير أنموذج فلاندرز في تحصيل مادة القو اعد لطلاب الصف الأول منوسط( المجمو عة التجريبية). 


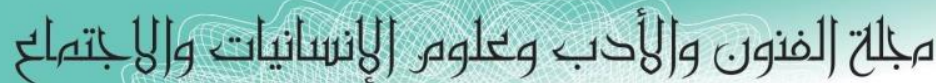

Journal of Arts, Literature, Humanities and Social Sciences

ISSN online: 2414 - 3383

ISSN print: 2616 - 3810

\section{العدد (41) آب - أغلسطس 2019}

هو إجر اء منظم لقياس ماكتسبه المتعلمون من حقائق ومفاهيم ومهار ات نتيجة لدر اسـة موضوع مـا، أو وحدة

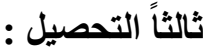

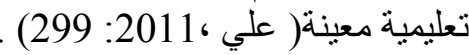

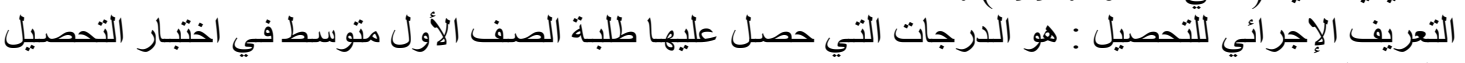
لمادة القو اعد الاعد التع

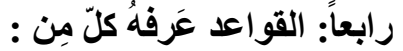

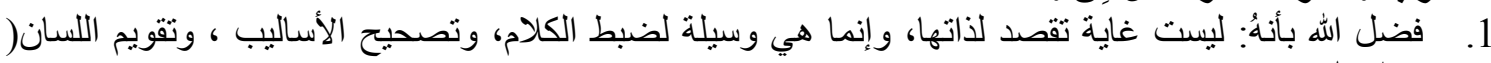
الكمات، ودر اسة العلاقة بينها داخل الجمل، وصلتها ببعضها البعض ( لافى،2015

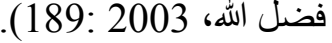
273: أما التعريف الإجر ائي لمادة القو اعد: الموضو عات التي يتضمنها كتاب اللغة العربية المقرر تدريسه للصف

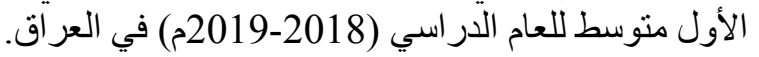

\section{جوانب نظريّة ودراستات الثاني}

الجاتب النظري :أنموذج فلاندرز المعرفي :

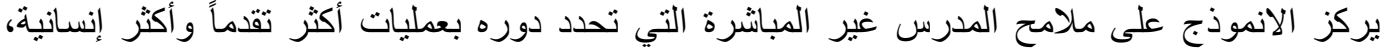

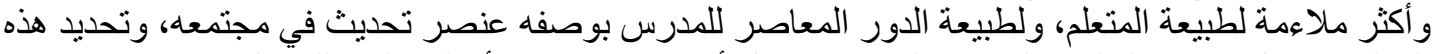

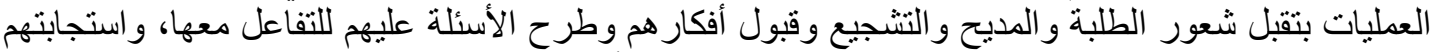

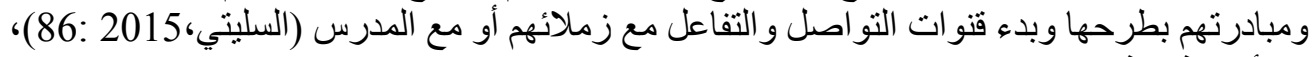

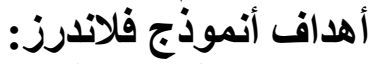

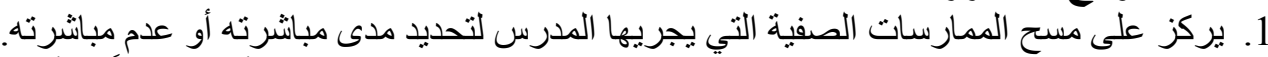
2. يركز النموذج على ملامح المدرس غير المباثرة التي تحدد دوره بعمليات أكثر تقدماً ، وأكثر إنسانية، و اكثر

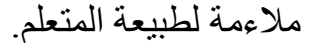
3. يركز على أسلوب الحوار و المناقثنة واستخدام أسلوب طرح الأسئلة والاجابـة، وهو من أهم العمليات المعرفيـة

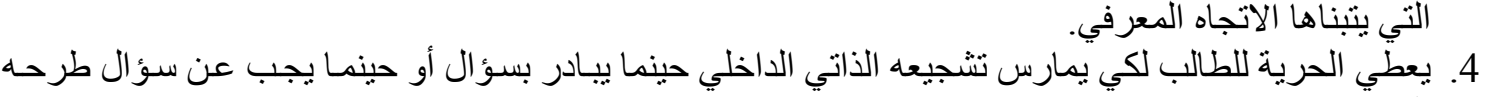
المدرس ( قطامي، 2003: 214: 214). 5. بركز على كل الإجر اءات بهذف نطي تطوير المتعلم و إنمائه و استغلال طاقاته المعرفية.

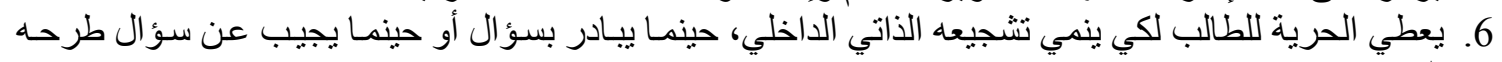
7. يعنى بطريقة غير مباشرة بعمليات صقل الخبر ات و المعارف وتجيز ها بهدف استحضار الخبرات المخزونة من

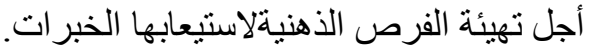

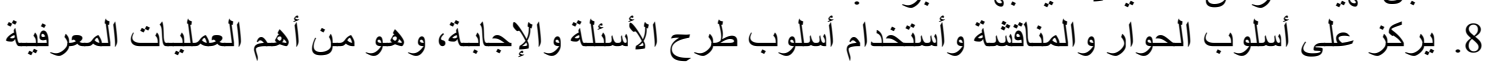

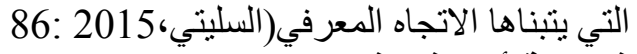
فرضية أنموذج فلاندرز

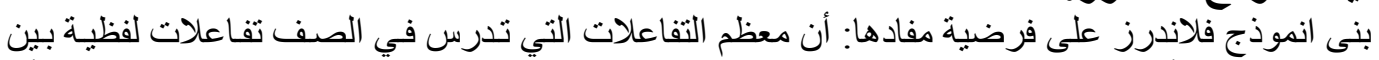

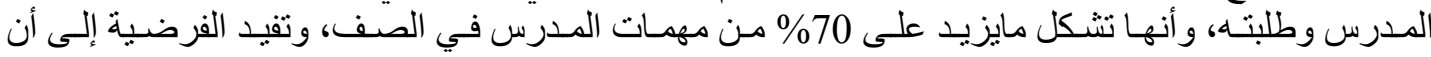
التفاعلات الصفية هي: الصغانية 1. 1 2. معظمها تفاعلات لفظية.

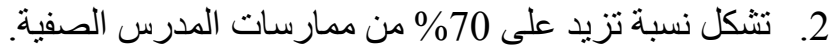

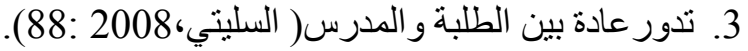




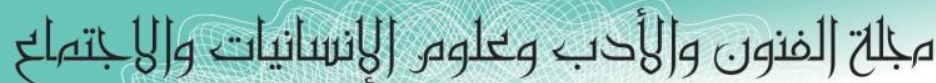

Journal of Arts, Literature, Humanities and Social Sciences

ISSN online: 2414 - 3383

ISSN print: 2616 - 3810

العدد (41) آب - أغسطس 2019

تصنفات نظام فلاتدرز

حدد فلاندرز (عشرة) تصنيفات فر عية لممارسات المدرس وتفاعله مع الطلبة في أثناء إدارتـه وتنظيمهـ للتعلم.

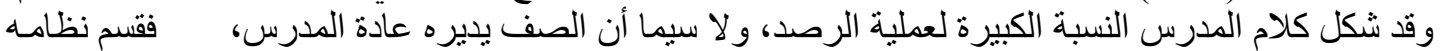

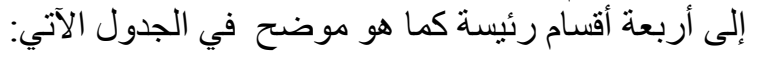

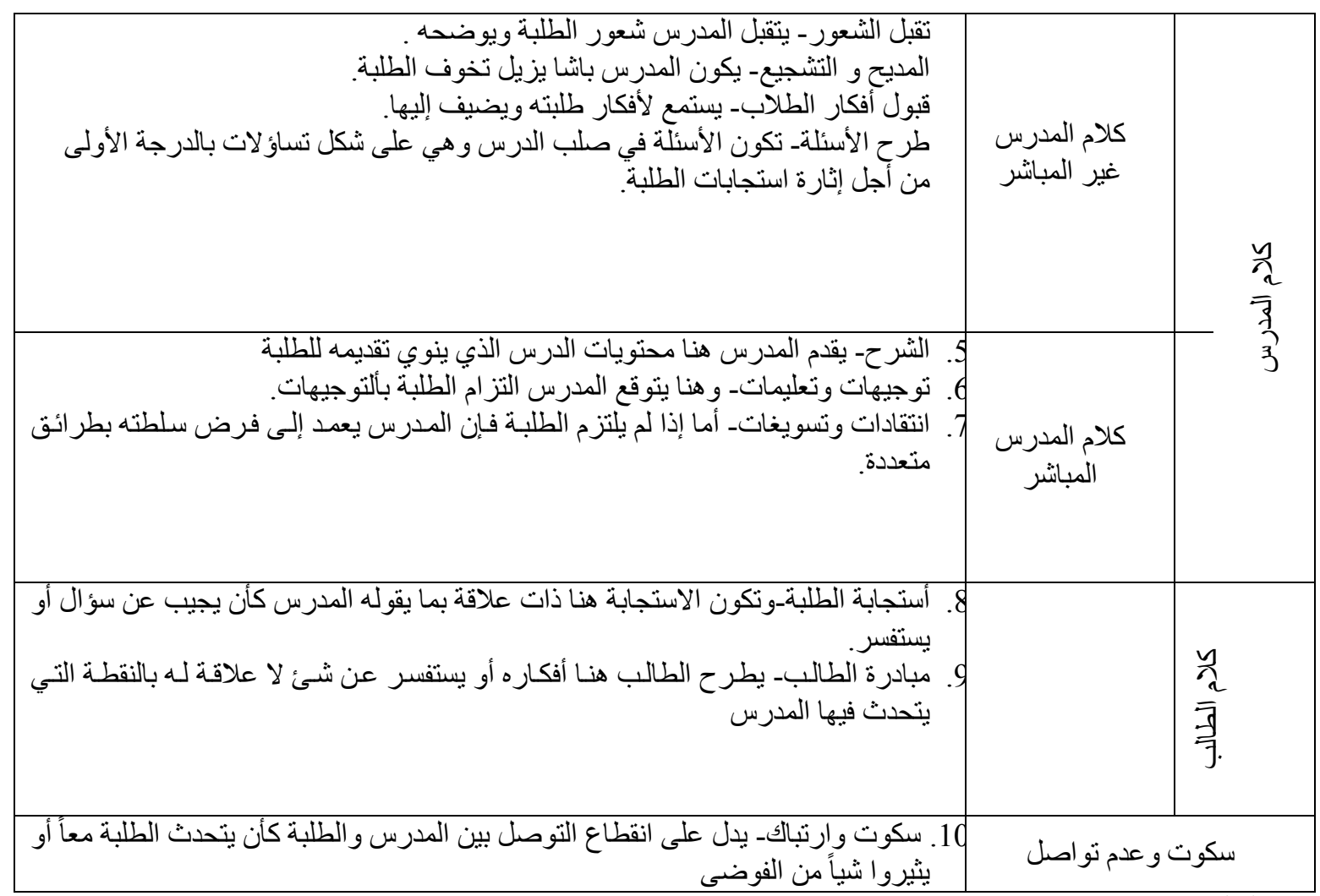

(90: السليتي، 2015 ( )

ثانياً. دراسات السايقة

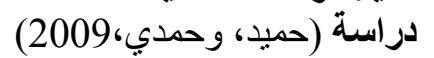

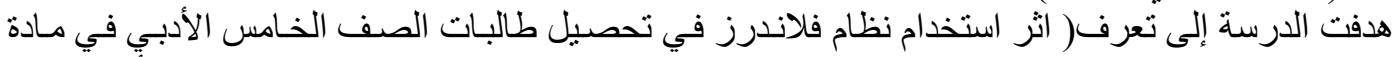

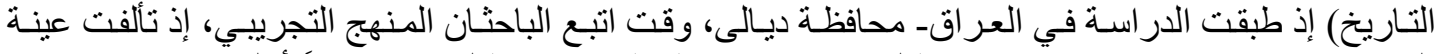

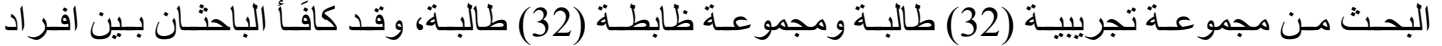

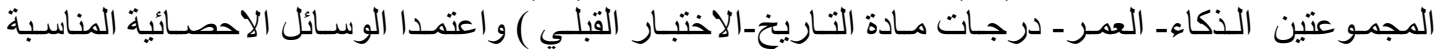

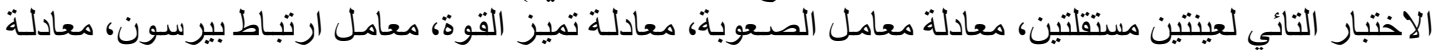

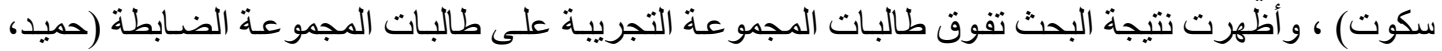

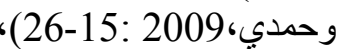

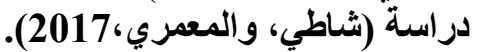

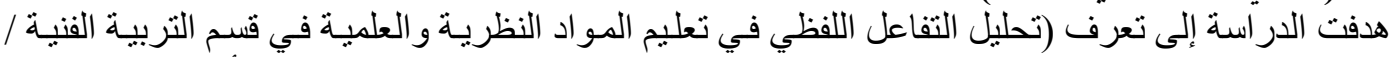

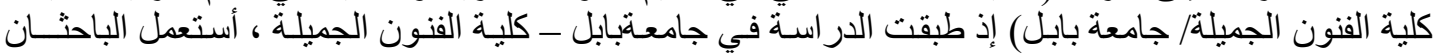

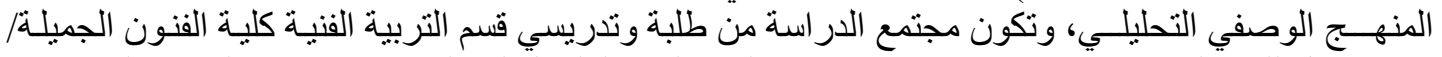

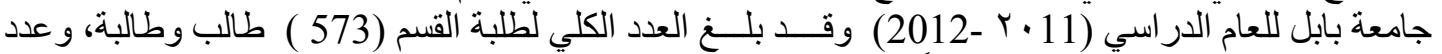

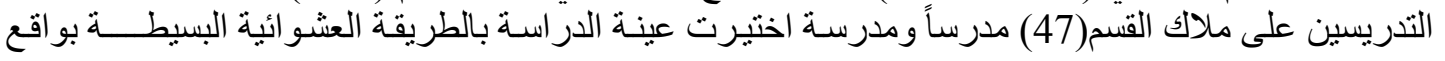




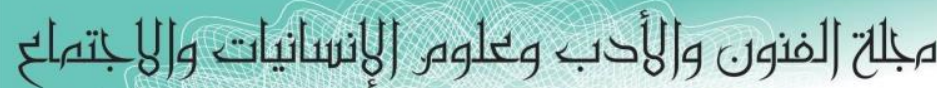

Jotrnal of Arts, Literature, Humanities and Social Sciences

ISSN online: 2414 - 3383

ISSN print: 2616 - 3810

\section{العدد (41) آب - أغسطس 2019}

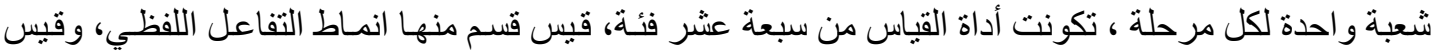

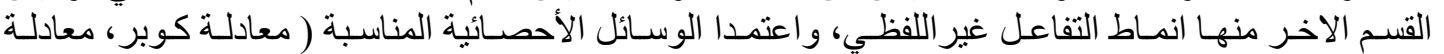

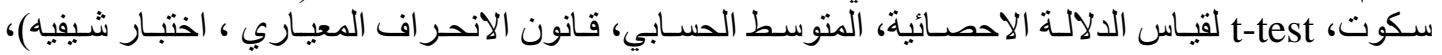

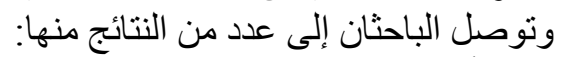

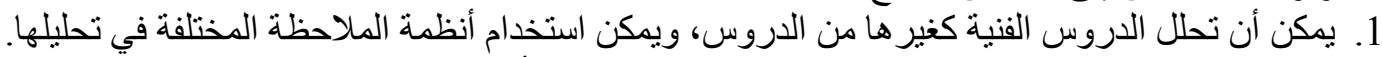

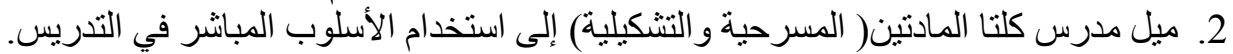

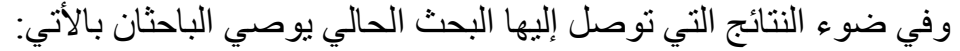

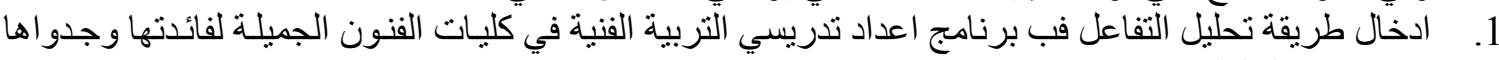
في تحسين السلوك.

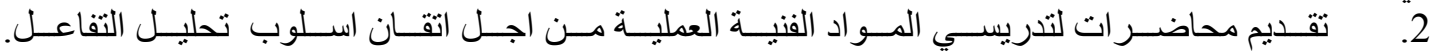

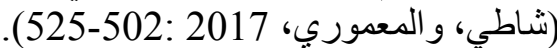

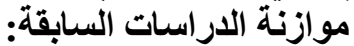
1. اختلفت أماكن إجر اء الدراستين ، فقد أجريت دراسـة (حميد، وحمدي،

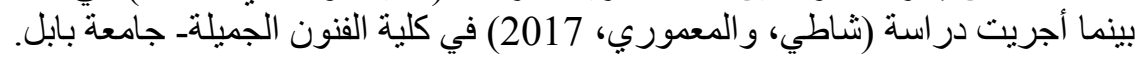

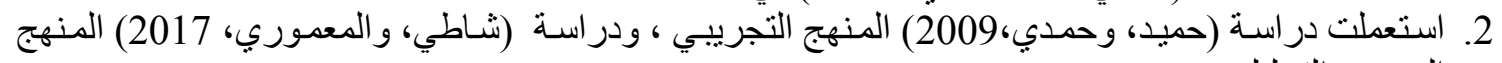

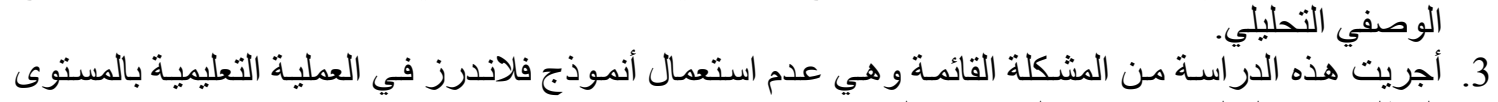

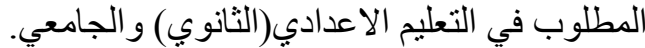

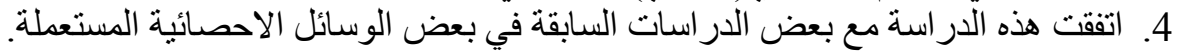

\section{المبحث الثالث إم الث منهج البحث و إجراءاته التهاث}

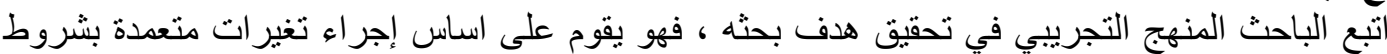

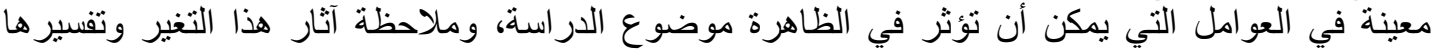

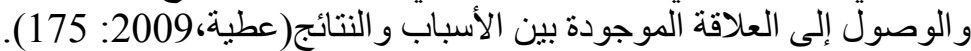

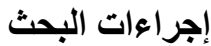

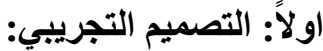

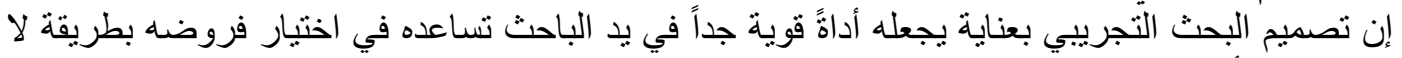

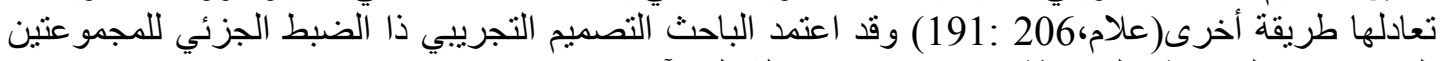
المتكافئتين ( التجريبة والضابطة) ،كما موضح في الثكل الآتي : الثكل (1) للتصميم التجريبي للبحث

\begin{tabular}{|c|c|c|c|}
\hline أداة البحث & المتغير التابع & المتغير المستقل & المجموعة \\
\hline \multirow{2}{*}{ اختبار التحصيل } & التحصيل & أنموذج فلاندرز المعرفي & التجرييية \\
\hline & التحصيل & & الضابطة \\
\hline
\end{tabular}




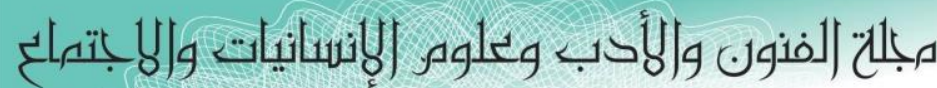

Journal of Arts, Literature, Humanities and Social Sciences

ISSN online: 2414 - 3383

ISSN print: 2616 - 3810

\section{العدد (41) آب - أغسطس 2019}

\section{ثانياً. مجتمـع البـحث وعينته:

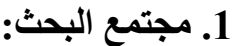

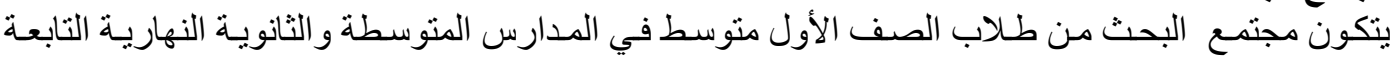

لممثلية وزارة التربية للنازحين في السليمانية.

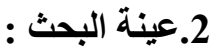

اختار الباحث بصورة قصدية مدرسة ثانوية روناكي للبنين عينةً لبحثه ، وبالطريقة العشو ائية البسيطة اختار

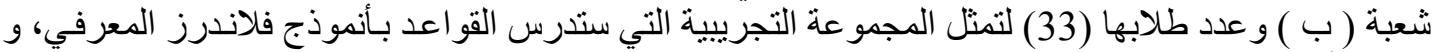

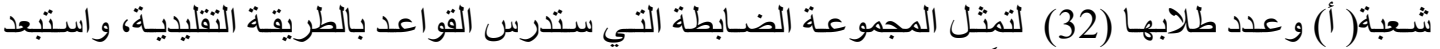

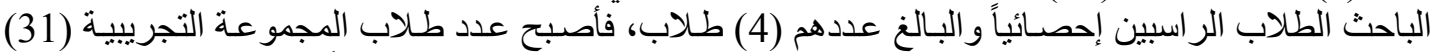
و عدد طلاب المجمو عة الضابطة (30) ، وبهذا يكون مجموع عينة البحث (61) طالباً. و الجدول رقم (1) يبين ذللك:

\begin{tabular}{|c|c|c|c|c|}
\hline بعد الاستبعاد الطلاب & عدد الطلاب & قدب الاستبعاد & الشعبة & المجمو عــة \\
\hline 31 & 2 & 33 & أ & التجرييــــــة \\
\hline 30 & 2 & 32 & ب ب & الضـابط لـــة \\
\hline 61 & 4 & 65 & 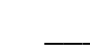 & المجمــــــــــع \\
\hline
\end{tabular}

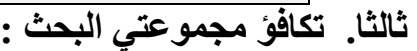

حرص الباحث قبل أن يبدأ التجربة على تكافؤ مجموعتي البحث إحصائياً في المتغير ات التي ينوقع أن نؤثر

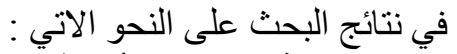

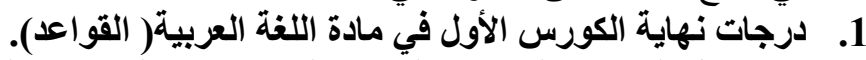

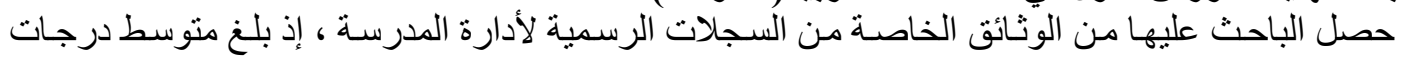

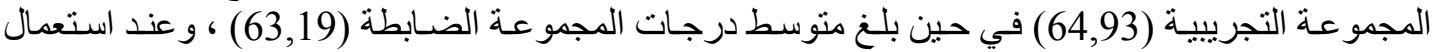

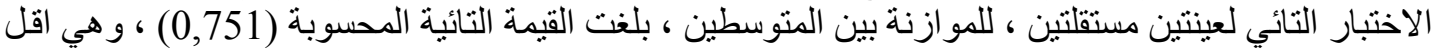

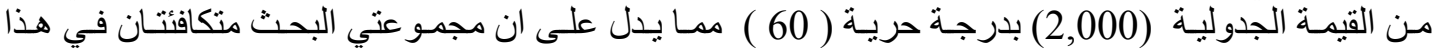
المتغير كما موضح في جدول (2) :

جدول (2) (2) (2)

\begin{tabular}{|c|c|c|c|c|c|c|c|c|}
\hline \multirow{2}{*}{$\begin{array}{c}\text { عندمستوى الاحئية } \\
\text { الالية } \\
0,05\end{array}$} & \multicolumn{2}{|c|}{ القيمة التائية } & \multirow{2}{*}{ لدرجة } & \multirow{2}{*}{ التباين } & \multirow{2}{*}{ المعباري } & \multirow{2}{*}{ الحسابي } & \multirow{2}{*}{ العينة } & \multirow{2}{*}{ المجمو عة } \\
\hline & ألجدولية & الدة بحو & & & & & & \\
\hline \multirow{2}{*}{ غير دالةً } & \multirow{2}{*}{2,000} & \multirow{2}{*}{0,751} & \multirow{2}{*}{60} & 125,59 & 11,20 & 64,93 & 31 & التجرييية \\
\hline & & & & 41,09 & 6,41 & 63,19 & 31 & الضابطة \\
\hline
\end{tabular}

2.

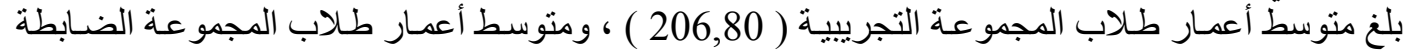
(207,22) ، الملحق (5) وباستعمال الاختبار التائي (t-test) لعينتين مستقلتين لمعرفة دلالـة الفرق ، اتضـح إن الن 


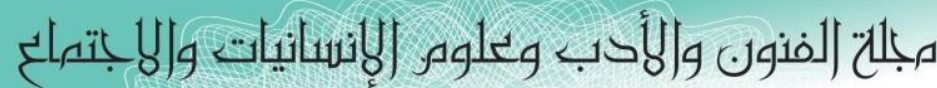

Journal of Arts, Literature, Humanities and Social Sciences

ISSN online: 2414 - 3383

ISSN print: 2616 - 3810

\section{العدد (41) آب - أغسطس 2019}

الفرق ليس بذي دلالة احصائية عند مستوى (0,005)، إذ بلغت القيمـة التائيـة المحسوبة (0,313) اقل من القية القيمة التائية الجدولية (2,000) وبدرجة حرية ( 60 ) و وذا يدل على النية ان مجموعتي البحث متكافئتان في هذا المتغير، وجدول (3) يوضح ذلك : 200ن

جدول (3)

\begin{tabular}{|c|c|c|c|c|c|c|c|c|}
\hline \multirow{2}{*}{ الاحصائية } & \multicolumn{2}{|c|}{ القيمة التائية } & \multirow{2}{*}{ لدرة } & \multirow{2}{*}{ التباين } & \multirow{2}{*}{ المعياري } & \multirow{2}{*}{ الحسابي } & \multirow{2}{*}{ العزيذ } & \multirow{2}{*}{ والمة } \\
\hline & ألجدول & والمحس & & & & & & \\
\hline \multirow[t]{2}{*}{ غير دالةًاً } & \multirow[t]{2}{*}{2,000} & \multirow[t]{2}{*}{0,313} & \multirow[t]{2}{*}{60} & 82,36 & 5,32 & 206,80 & 31 & التيبة \\
\hline & & & & 27,11 & 5,20 & 207,22 & 31 & الضة \\
\hline
\end{tabular}

رابعاً: ضبط المتغيرات الاخيلة :

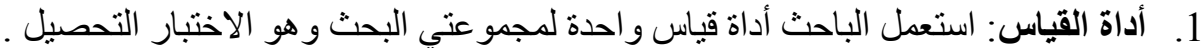

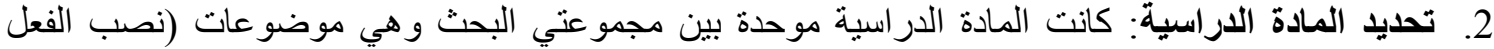

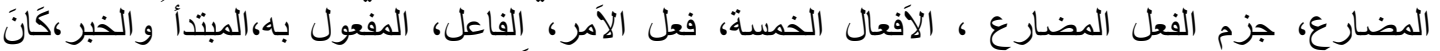

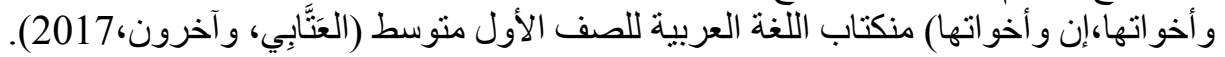

خامساً : صياغة الأهداف السلوكية :

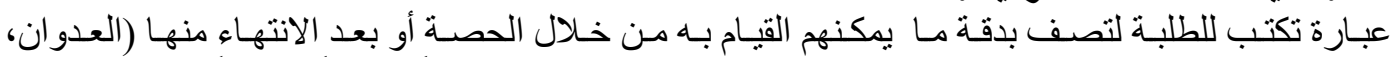

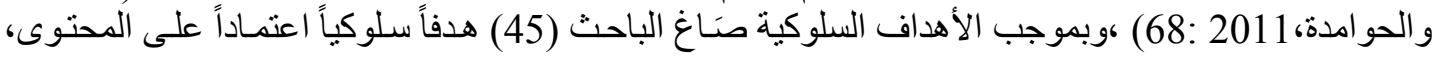
موزعة بين مستويات تصنيف بلوم في المجال المعرفي وهي ( التذكر ، الفهم ، التطبيق)، اعنمد الباحث على التى نسبة، و هي (85\%) من مو افقة الخبر اء و المحكمين.

سادساً: إعداد الخطط التدريسية :

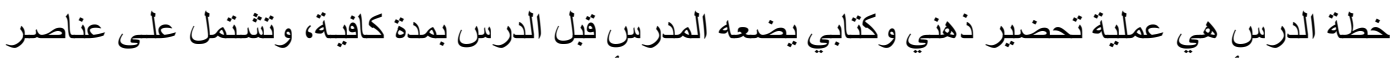

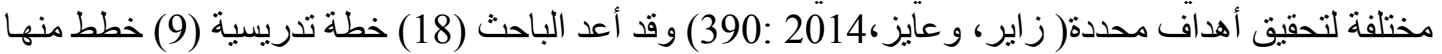

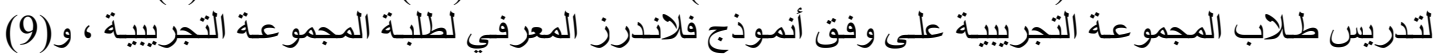
خطط على وفق الطريقة التقلدية لطلاب المجموعة الضيابطة .

سابعاً : أداة البحث (اعداد الاختبار )

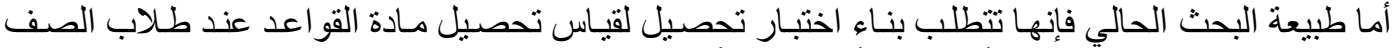

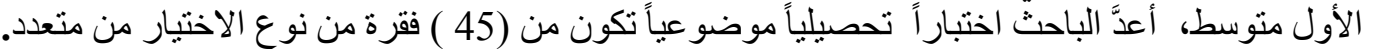

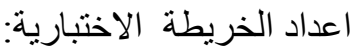

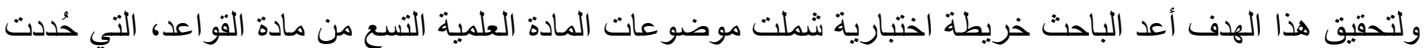
للتجربة والأهداف السلوكية الموزعة على مستويات الهجال المعرفي لتصنيف بلوم (Bloom).(تذكر، الفهم، التطبيق) وجدول(4) يوضح ذللك. 


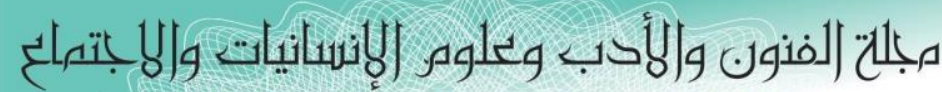

Journal of Arts, Literature, Humanities and Social Sciences

ISSN online: 2414 - 3383

ISSN print: 2616 - 3810

العدد (41) آب - أغسطس 2019

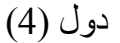

جدول المواصفات ( الخريطة الاختبارية )

\begin{tabular}{|c|c|c|c|c|c|c|c|c|c|c|}
\hline \multirow[b]{2}{*}{$\frac{\text { 告 }}{\text { 离 }}$} & \multicolumn{3}{|c|}{ عدد فقر ات كل مستوى } & \multicolumn{3}{|c|}{ عدد الأهداف السلوكية } & \multirow{2}{*}{$\frac{\text { 㝵. }}{\frac{3}{3}}$} & \multirow[b]{2}{*}{$\frac{\frac{y}{7}}{\frac{g}{g}}$} & \multirow[b]{2}{*}{$\begin{array}{l}\overline{3} \\
\dot{3} \\
y \\
\bar{y}\end{array}$} & \multirow[t]{2}{*}{ 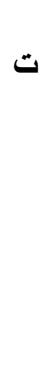 } \\
\hline & 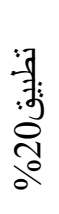 & 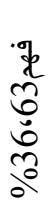 & 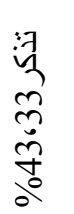 & 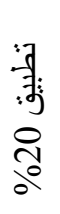 & $\begin{array}{l}\text { se } \\
n \\
\cdots \\
0 \\
0\end{array}$ & 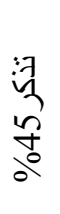 & & & & \\
\hline 5 & 1 & 2 & 2 & 2 & 4 & 4 & $\% 16 \cdot 66$ & $\begin{array}{l}\mathbf{1} \\
\mathbf{0}\end{array}$ & نصب الفعل & 1 \\
\hline 5 & 1 & 2 & 2 & 2 & 4 & 4 & $\% 16 \cdot 66$ & $\begin{array}{l}1 \\
\mathbf{0}\end{array}$ & المضارع الفعل & 2 \\
\hline 5 & 1 & 2 & 2 & 2 & 3 & 5 & $\% 16 \cdot 67$ & $\begin{array}{l}1 \\
0\end{array}$ & الخمسة & 3 \\
\hline 5 & 1 & 1 & 3 & 2 & 3 & 5 & $\% 16 \cdot 67$ & $\begin{array}{l}1 \\
0\end{array}$ & فعل الآمر & 4 \\
\hline 5 & 1 & 2 & 2 & 2 & 4 & 4 & $\% 16 \cdot 66$ & $\begin{array}{l}1 \\
\mathbf{0}\end{array}$ & الفاعل & 5 \\
\hline 5 & 1 & 1 & 3 & 2 & 3 & 5 & $\% 16 \cdot 67$ & $\begin{array}{l}\mathbf{1} \\
\mathbf{0}\end{array}$ & المفعول به & 6 \\
\hline 5 & 1 & 2 & 2 & 2 & 4 & 4 & $\% 16 \cdot 67$ & $\begin{array}{l}\mathbf{1} \\
\mathbf{0}\end{array}$ & و الخبتد & 7 \\
\hline 5 & 1 & 2 & 2 & 2 & 4 & 4 & $\% 16 \cdot 66$ & $\begin{array}{l}1 \\
0\end{array}$ & وَأخوانها & 8 \\
\hline 5 & 1 & 2 & 2 & 2 & 4 & 4 & $\% 16 \cdot 67$ & $\begin{array}{l}1 \\
\mathbf{0}\end{array}$ & إن و أخو اتها & 9 \\
\hline 45 & 9 & 16 & 20 & 18 & 33 & 39 & $\% 100$ & $\begin{array}{l}9 \\
0\end{array}$ & مجموع & \\
\hline
\end{tabular}

ثامناً:العينة الاستطلاعية

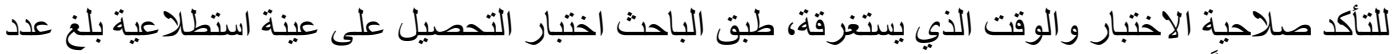

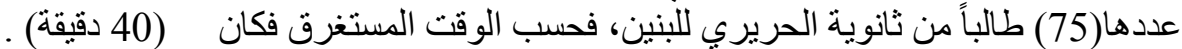

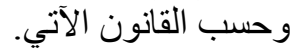
زمن الطالب الأول + زمن الطالب الثناني + زمن الطالب الثالث +زمن اخر طالب 


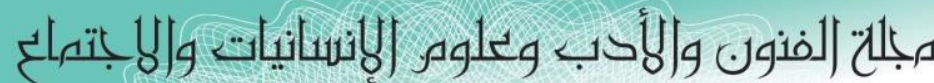

Journal of Arts, Literature, Humanities and Social Sciences

ISSN online: 2414 - 3383

ISSN print: 2616 - 3810

\section{العدد (41) آب - أغسطس 2019}

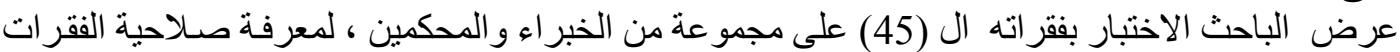

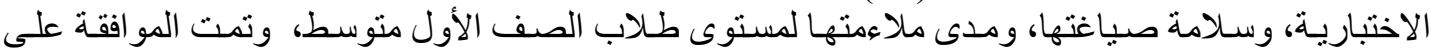

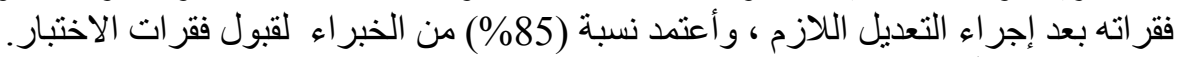

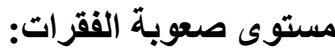

حسب الباحث معامل صعوبة كل فقرة من فقرات الاختبار ، فوجدها تتر اوح بين (0.47) و(0.76) وبهذا

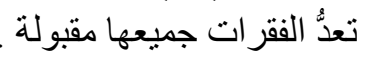

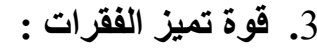

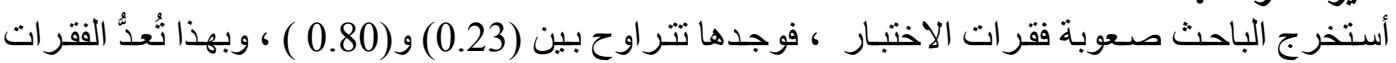
مقبولة.

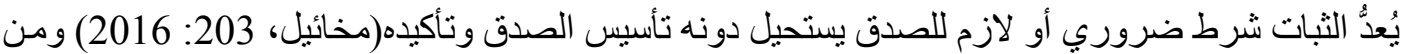

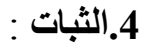

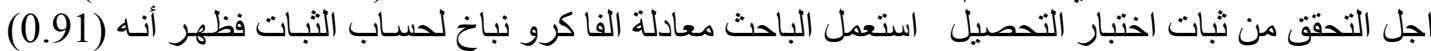
و هو معامل ثبات جيد.

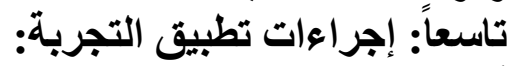

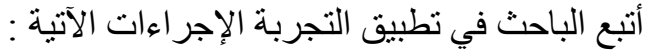
1. عند استكمال الباحث متطلبات إجر اء التجربة و تحقيق التكافؤ و تحديد المادة العلمية بدأ الباحث بتطبيق التجربة

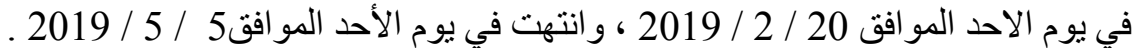

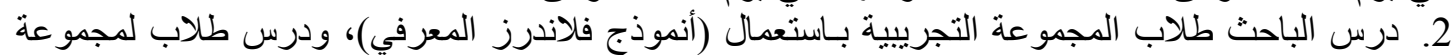
الضابطة بالطريقة التقليدية.

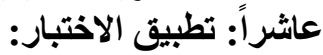

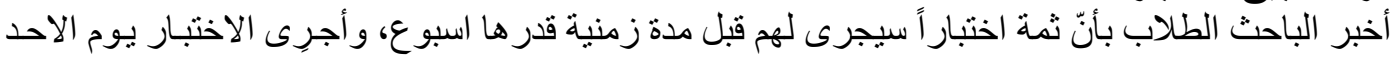

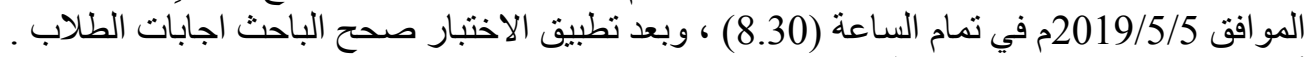
أحدى عشر: الوسائل الإحصائية:

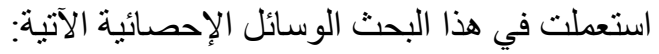

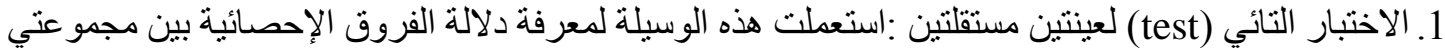
البحث عند التكافؤ في المتغير ات الآتينة

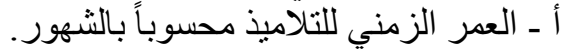

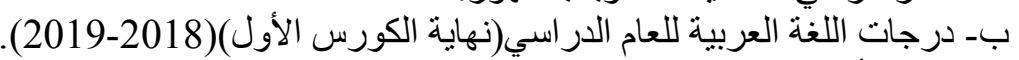
2. معادلة ألفاـ كرونباخ: استعملت لمعرفة ثبات فقر ات ات اختبار التحصيل. 3.معل ارتباط بيرسون.

\section{المبحث الرابع \\ عرً النتائج وتفسير ها الراع}

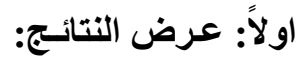

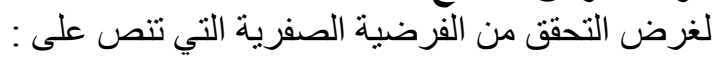

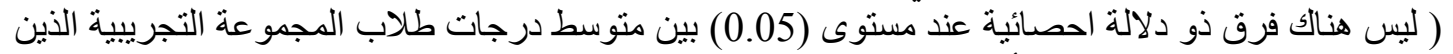

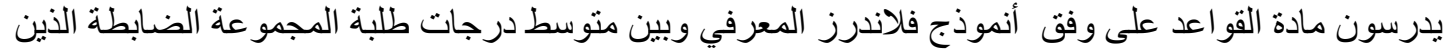
يدرسون مادة القو اعد على وفق الطريقة التقليدية في اختبار التحصيل) التيلئ.

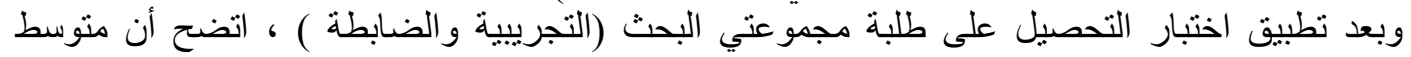

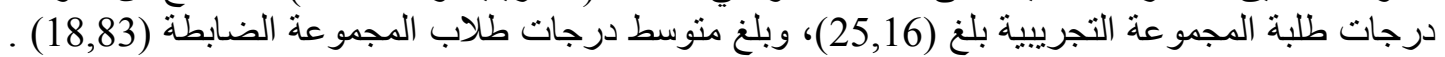

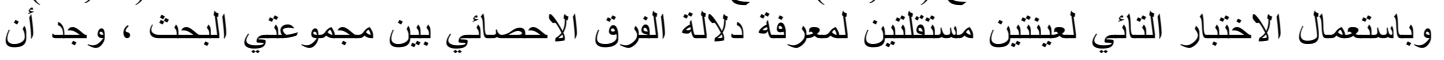




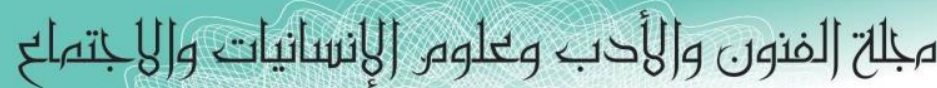

Journal of Arts, Literature, Humanities and Social Sciences

ISSN online: 2414 - 3383

ISSN print: 2616 - 3810

\section{العدد (41) آب - أغسطس 2019}

هناك فرقاً ذا دلالة احصائية عند مستوى (065،05) وبدرجة حرية (59) ، إذبة كانت القيمة التائية المحسوبة

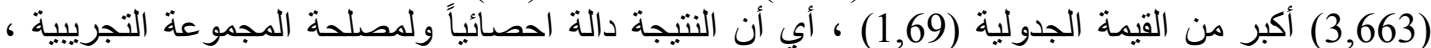

وبذللك ترفض الفرضية الصفرية وجدول (4) الفية (1) يوضح ذلك ألك .

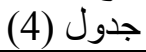

\begin{tabular}{|c|c|c|c|c|c|c|c|}
\hline \multirow[b]{2}{*}{ عندوى الدالة } & \multicolumn{2}{|c|}{ القيمة التائية } & \multirow{2}{*}{ لدرجة } & \multirow{2}{*}{ الالحرباف } & \multirow[b]{2}{*}{ الحسابي } & \multirow{2}{*}{ العراد } & \multirow[b]{2}{*}{ المجمو عة } \\
\hline & الجدولية & المحسو & & & & & \\
\hline \multirow{2}{*}{ دال احصائياً } & \multirow{2}{*}{1.69} & \multirow{2}{*}{3.662} & \multirow{2}{*}{59} & 5.398 & 25.16 & 31 & التجرييية \\
\hline & & & & 7.905 & 18.83 & 30 & الضـابطة \\
\hline
\end{tabular}

يمكن تفسير تفوق طلاب المجمو عة التجريبية على طلاب المجو عة الضـابطة في اختبار تحصبل مـادة قو اعد ثانياً: : تفسير النتائج :

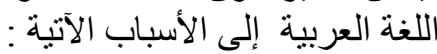

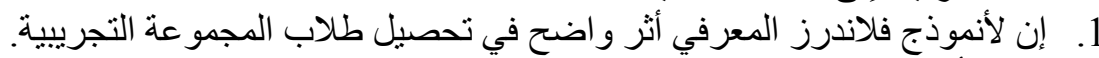

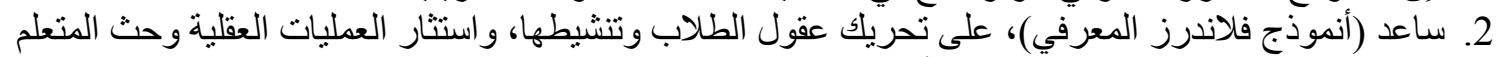

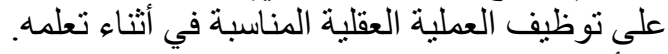

3. لأنموذج فلاندرز المعرفي دور مهم في جعل الطلاب من متلفين إلى مشاركين وفاعلين ونشيطين ولهم وجود داخل غرفة الصف.

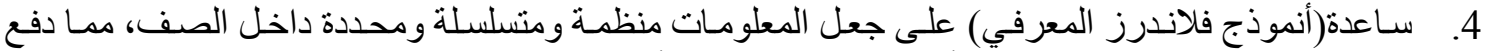

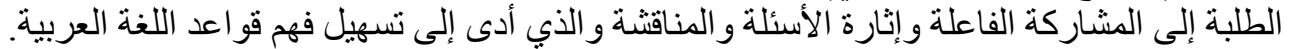

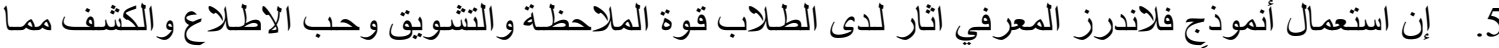

جعلهم اكثر نشاطاً.

\section{المبحث الخامس

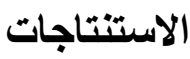

في ضوء نتائج البحث استنتج الاحث الاستتناجات الآتية:

1. إنّ استعمال أنموذج فلاندرز المعرف في في تدريس طلاب المجموعة الإنة التجريبية أدّى الى فهم القواعد واستيعابها بعيداً عن الحفظ والتئلقين.

2. أدّى استعمال أنموذج فلاندرز المعرفي إلى تسهيل عملية التدريس وتوفير الجهد و الوقت للطلاب و المدرس.

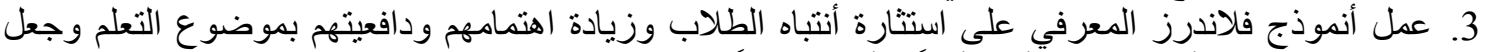

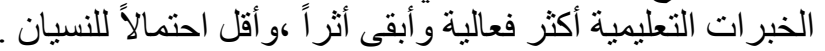

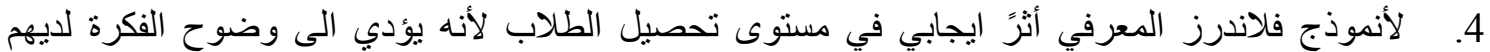

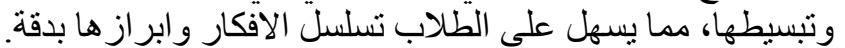

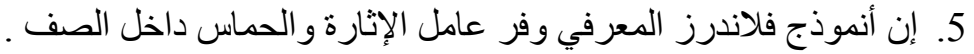

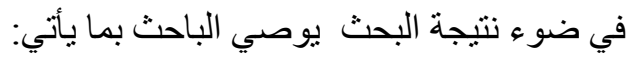

1. عقد دور ات تدرييية لمدرسي ومدرسات اللغة العربية لتعريفهم بأهميـة الأستر اتيجات و النمـإذج الحديثة، ومنها

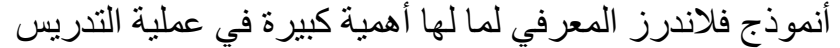
2. استعمال الاستر اتيجيات التدريسية والنمإذجية كبيرة التعليمية الحديثة، التي تساعد الطلاب على الفهم و الاستيعاب بعيداً عن الحفظ و التلقين . 3. تحفيز مدرسين ومدرسات اللغة العربية وتشجيعهم على استعمال أنموذج فلاندرز المعرفي عن طريق تدريبهم بها من قبل المؤسسات التربوية. 


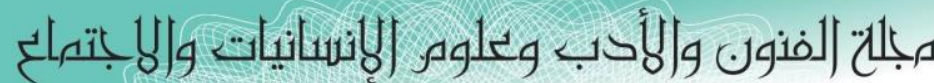

Journal of Arts, Literature, Humanities and Social Sciences

ISSN online: 2414 - 3383

ISSN print: 2616 - 3810

\section{العدد (41) آب - أغسطس 2019}

4. الاهتمام بأستعمال النمإذج التعليمية الحديثة في عملية التعليم لآنها تساعد الطلاب على ترسيخ المادة العلمية في

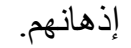

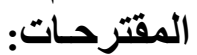

استكمالاً للبحث الحالي يقتر ح الباحث إجر اء البحوث الآتية:

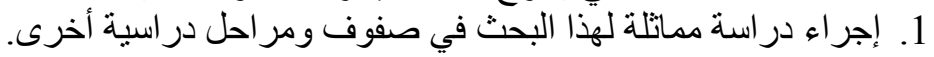
2. إجر اء در اسة مماثلة لهذا الدر اسة في فروع اللغة فئة العربية الآخرى.

المصادر

1. أبو زيد، سالم عطية، الوحيز في أساليب التدريس، دار جرير للنشر و التوزيع ، عمان، 2013م.

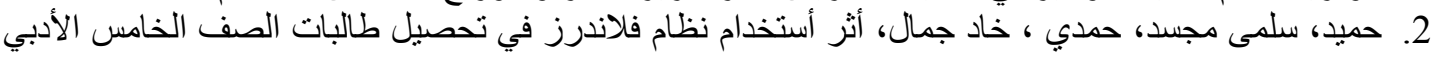

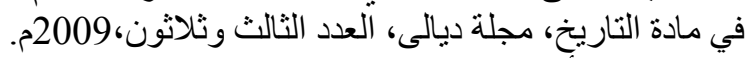

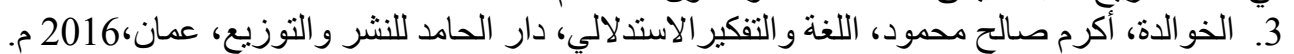

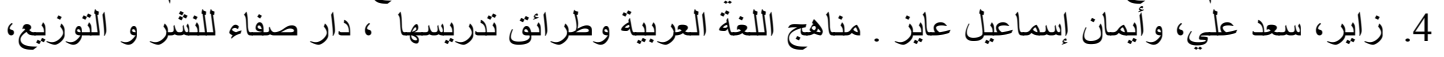

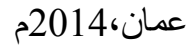
5. زاير، وداخل ، سعد علي ، سماء تركي. اتجاهات حديثة في تدريس اللغة العربية، دار المرتضى طبع ونشر

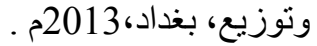

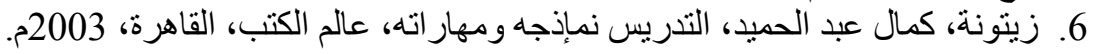

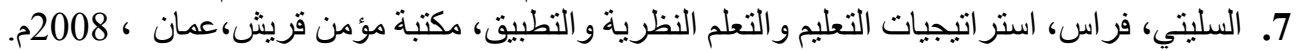

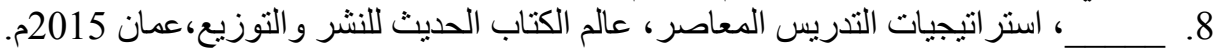
9. السامر ائي، نبيهة صالح، الإستر اتجيات الحديثة في طرق تدريس العلوم،دار المناهج للنشر و التوزيع ، عمان، 2013.

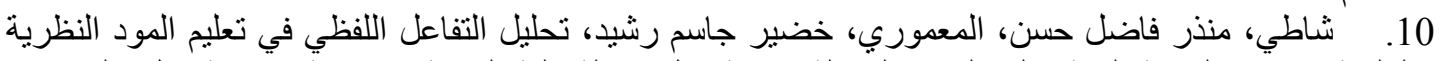

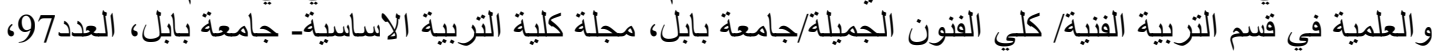
2017

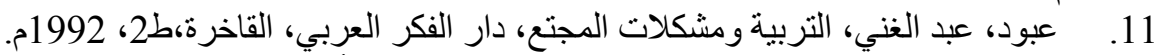
12.

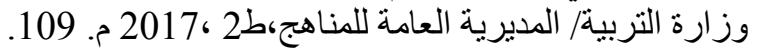
13. و التوزيع و الطباعة، عمان، 2011م. 2013.

14. العسكري، كفاح يحيى صالح، فلسفات تربوية، أصولها، مدارسها،آر ائها، دار أمجد للنشر و التوزيع ، عمان 2017،

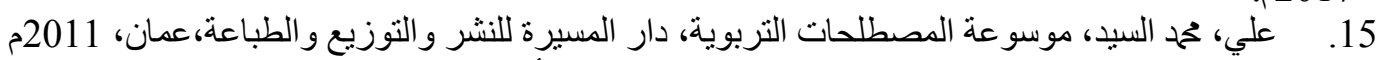

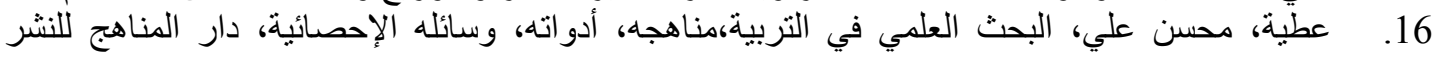

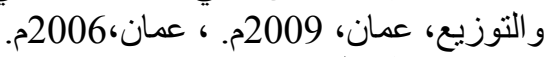
17.

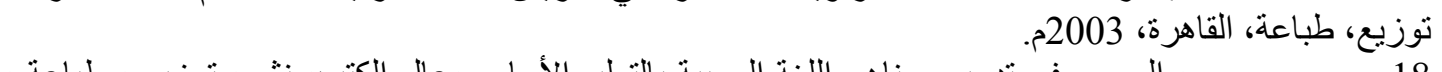

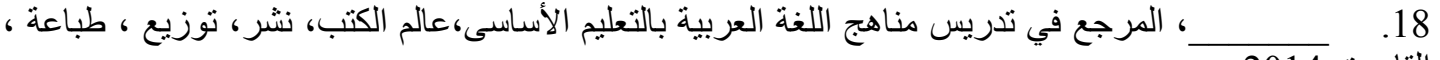

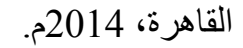
19. الكيلاني،ماجد عرسان، التربية و التجديد، دار القلم للنشر و التوزيع، دبي، 2005م، 2012.

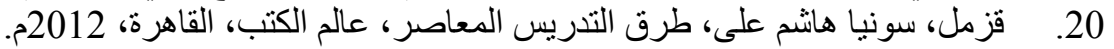

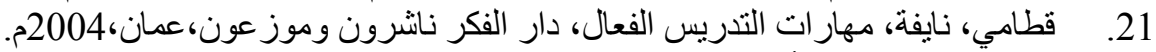

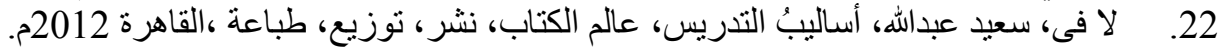

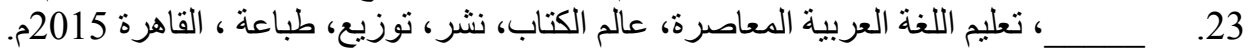

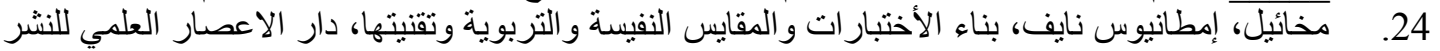

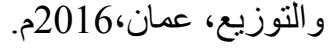




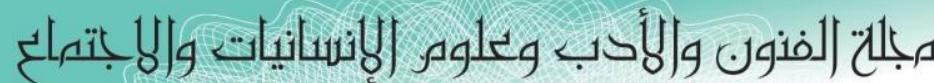

Jotrnal of Arts, Literature, Humanities and Social Sciences

ISSN online: 2414 - 3383

ISSN print: 2616 - 3810

العدد (41) آب-أغسطس 2019

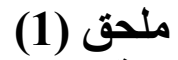

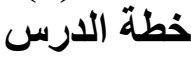

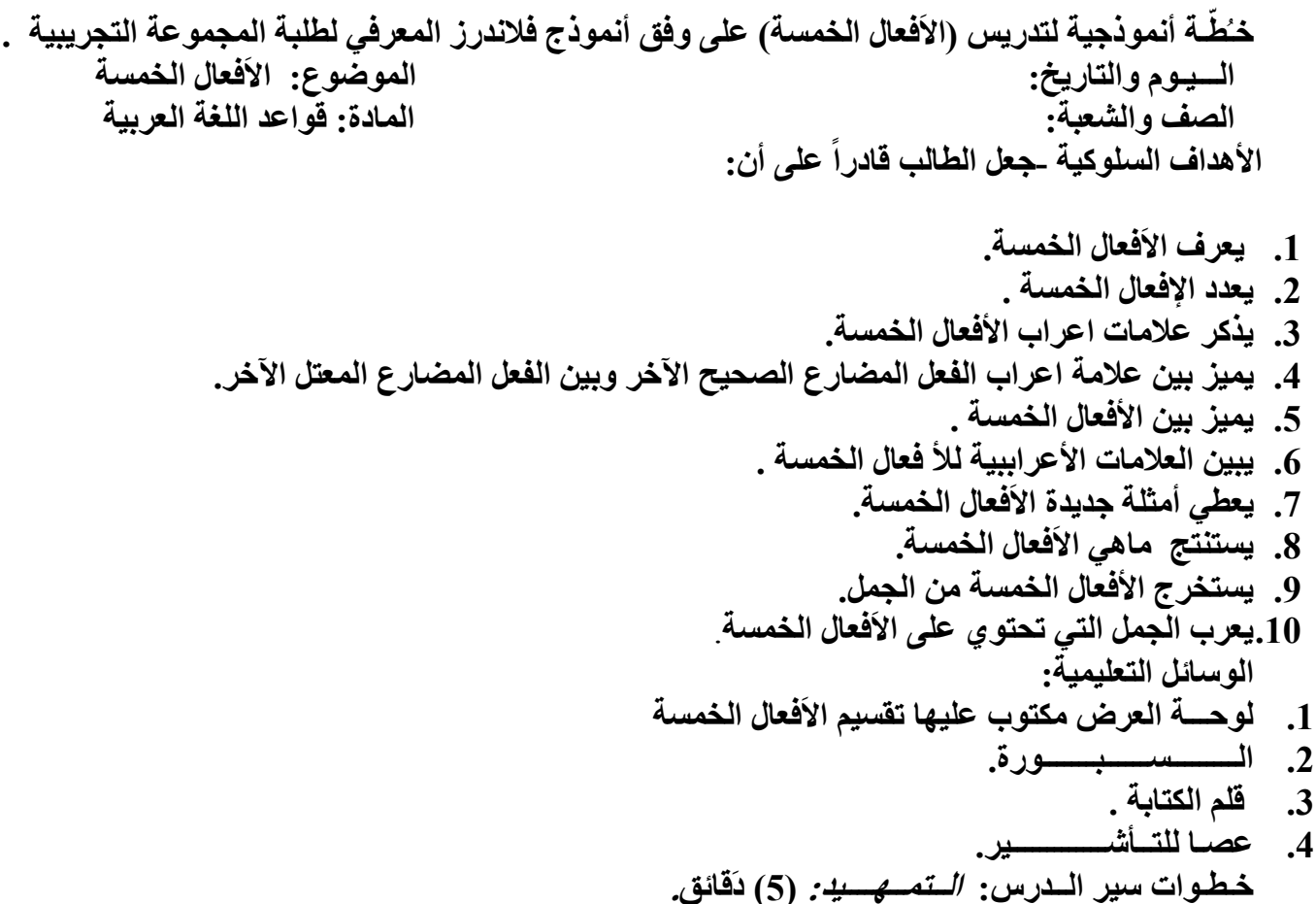

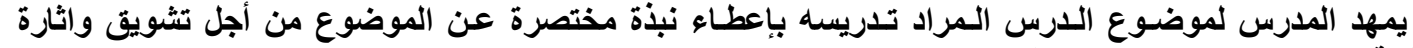

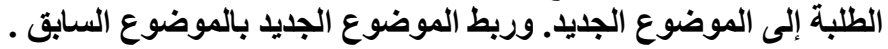

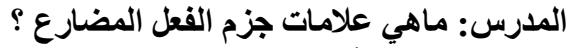

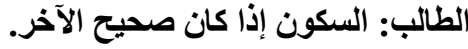

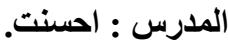

طالب آخر: إذا كان معتل الآخر يحذف حرف العلة وتعويض بحركة مشابهة له.

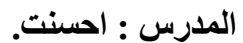

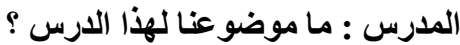

الطالب: الآفَعال الخمسة.

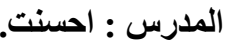

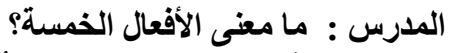

الطالب: كل فعل مضارع اتصل به الفهُ الفُ الاثنين أو واؤ الجماعة أو ياء المخاطبة. المدرس : المسنت.

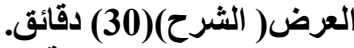

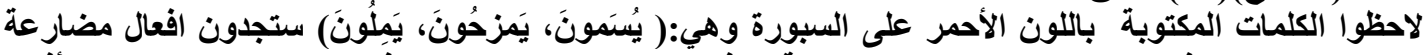

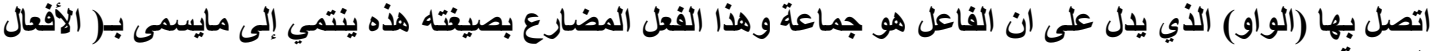

(الخمسة)

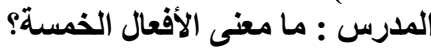

الطالب: كل فعل مضارع اتصل بهله أحد الضمائر الفُ الفُ الاثنين، أو واوُ الجماعة ،أو ياء المخاطبة)

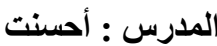
المدرس: مإذاتعني الالف في الف الاثنين ؟ الطالب: تعني أن الفاعل شخصين. المدرس: المسنت.

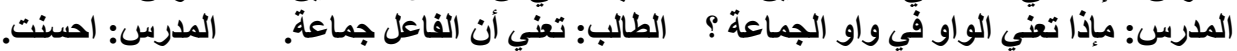




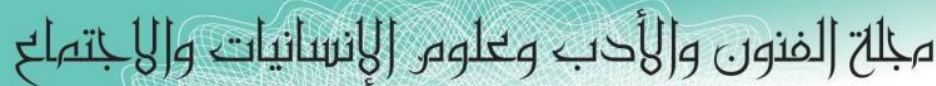

Journal of Arts, Literature, Humanities and Social Sciences

ISSN online: 2414 - 3383

ISSN print: 2616 - 3810

العدد (41) آب- أغسطس 2019

المدرس: مإذا تعني الياء في ياءُ المخاطبة ؟ الطالب : تعني للمؤنثة الفاعلة. المدرس: احسنت.

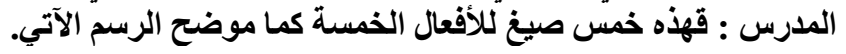

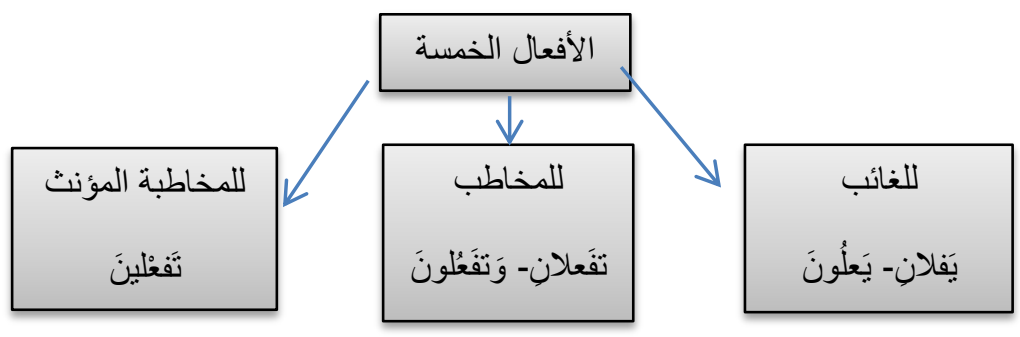

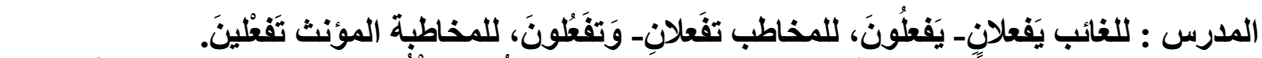

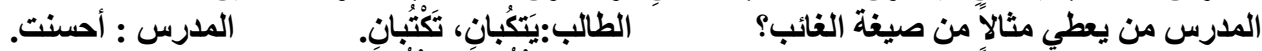

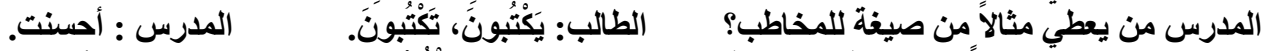

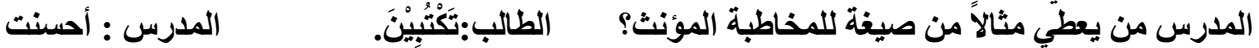

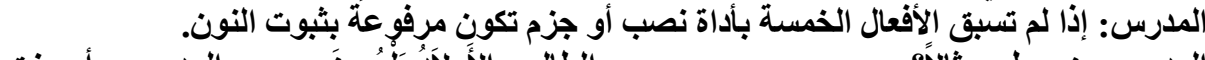

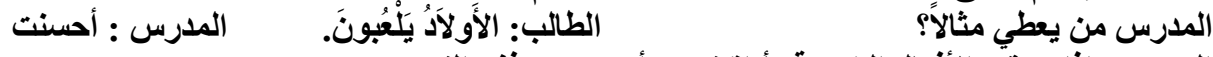

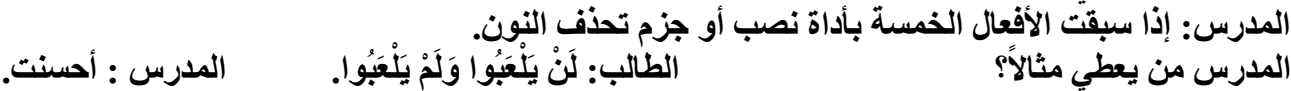

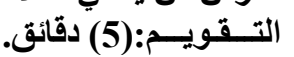

في نهاية الدارس يطانب المدرس من الطلبة كتابة صيغة الأفعال الخمسة مع الأمثلة في ورقة الاختبار وتجمع

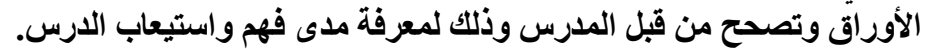

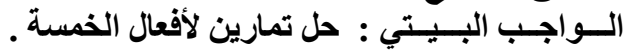

